\title{
THRESHOLD EFFECT OF INFORMATION TECHNOLOGY INFRASTRUCTURE ON TOURISM SECTOR DEVELOPMENT: EVIDENCE FROM TOP 10 AFRICAN DESTINATIONS
}

\author{
Abobaker Al.Al. HADOOD* \\ University of Zawia, Department of Finance and Banking, Zawia, Libya, e-mail: a.hadood@zu.edu.ly \\ Ridha Ali Mohamed BEN SALEH \\ University of Zawia, Department of Finance and Banking, Zawia, Libya, e-mail: bensaleh@zu.edu.ly \\ Khaled AB EMGEG \\ University of Zawia, Department of Finance and Banking, Zawia, Libya, e-mail : k.emgeg@zu.edu.ly
}

\begin{abstract}
Citation: Hadood, A.Al.Al., Ben Saleh, R.A.M., \& Emgeg, K.AB. (2021). THRESHOLD EFFECT OF INFORMATION TECHNOLOGY INFRASTRUCTURE ON TOURISM SECTOR DEVELOPMENT: EVIDENCE FROM TOP 10 AFRICAN DESTINATIONS. GeoJournal of Tourism and Geosites, 39(4spl), 1336-1345. https://doi.org/10.30892/gtg.394spl03-776
\end{abstract}

\begin{abstract}
Tourism has become an information-intensive business that heavily relies on ICT to provide information and conduct transactions for consumers of touristic products and services. Thus, ICT infrastructure would play a major role in the development of the tourism sector. This paper aims to investigate the threshold effect of ICT infrastructure on tourism sector development in top10 African tourism destinations including ; Botswana, Egypt, Kenya, Morocco, Namibia, Rwanda, South Africa, Tanzania, Tunisia, Uganda. To do so, a double panel threshold regression model utilized over the period 2004 to 2017 . The empirical results revealed a new perspective that there is a double-threshold effect of ICT infrastructure on the development of tourism sector, indicating a nonlinear effect of ICT infrastructure on the development of tourism sector in top 10 African tourism destinations. More specifically, the empirical results reveal that ICT infrastructure weakly and positively derives the number of intentional tourism arrivals and international tourist receipts when the level of ICT infrastructure is less or equal to the first threshold, while it strongly and positively derives the number of intentional tourism arrivals and international tourist when the level of ICT infrastructure is less or equal to the first and second thresholds. Thus, this paper provides important implications for policy makers, in that maximizing the benefits from information technology in developing tourism sector can be achieved when its level between certain critical threshold values.
\end{abstract}

Key words: ICT infrastructure, tourism sector development, top 10 African destinations, panel threshold regression model

\section{INTRODUCTION}

Tourism is one of the fastest growing sectors in the global economy. According to the World Travel and Tourism Council, (WTTC), the tourism sector accounted for 8.8 trillion dollars (10.4\%) of the total global gross domestic product (GDP) in 2018. Moreover, the contribution the sector makes to global GDP was 1.7 times higher than the mining sector, 1.5 times higher than banking and automotive manufacturing, and 1.4 times higher than agriculture. Africa is particularly significant to the tourism market with its tourism sector, founded on cultural and historical attractions, being considered one of the essential pillars of African economies (Butler and Rogerson, 2016; Okupe et al., 2018). The tourism sector in Africa has become one of the most significant contributors to economic growth as it comprises $8.5 \%$ of total GDP. Tourism is a fast growing sector in Africa with a growth rate of $5.6 \%$ in 2018, second only to Automotive manufacturing with $7.1 \%$. It is also fourth in terms of job creation with 24.3 million employees in tourism, which accounts for $6.7 \%$ of total employment (WTTC, 2018).

Considering this data, it can be concluded that tourism has the potential to meaningfully accelerate Africa's economic development. More specifically, it can be seen that in countries that contain a top 10 tourist destinations, the tourism sector is one of the leading sectors in their economies. Statistic, (2018), the tourist sector accounts for nearly 25 million Pules (12.6\%) to Botswanan GDP, 496.4 billion (9.3\%) to Egyptian GDP, 137.8 billion Dirhams (11.7\%) to Moroccan GDP, 806.3 billion Kenyan Shillings $(8.2 \%)$ to Kenyan GDP, 28.610 million Namibian dollars (14.7\%) to Namibian GDP, 354.9 billion South African Rand (7\%) to South African GDP, 922 billion Rwandan Franc (10.2\%), 5.141.1 billion Tanzanian Shillings (10.7\%) to GDP, 15.761 million Tunisian dinars (13.9\%) to GDP, 6.622 billion Ugandan Shillings (5.6\%) to GDP. In addition, the tourism industry provides millions of jobs and thereby reduces unemployment rates, with $10 \%$ of the world's workers being employed in the tourism sector. According to the WTTC, in 2019 tourism sector provides 92.3 thousand jobs in Botswana, 2.490 million jobs in Egypt, 1.336 million jobs in Morocco, 1.579 million jobs in Kenya, 114.6 thousand jobs in Namibia,1.483 million jobs in South Africa, 331.2 thousand jobs in Rwanda, 1.550 million jobs in Tanzania, 373.5 thousand jobs in Tunisia, and 536.6 thousand jobs in Uganda. Despite this, the development of this sector in African countries is still at remarkably low levels compared to other regions. For example, in 2018, the number of international tourist arrivals was only 47.6 million in Africa, compared to 519.5 million and 320.2 million in European Union and Asia and pacific countries respectively.

Information and communication technology (ICT) infrastructure plays a major role in the development of the tourism sector through its influence on tourism firms' operations and performances. The spread and advisement of ICT infrastructure

\footnotetext{
* Corresponding author
} 
offer instruments that facilitate the construction of new tourism businesses and the restructuring of existing one (Buhalis, 1998, 2003). Also, the spread and advisement of ICT infrastructure can reshape and change the nature of tourist firms' products, processes, businesses and competition (Buhalis, 1998; Law and Jogaratnam 2005). Furthermore, ICT provides several strategies that tourism firms can benefit from, namely: creating barriers to entry; making provided products and services more distinguishable; reducing products' distribution channels; improving pricing competition abilities; diminishing product supply costs and facilitating supply products; as well as, increasing cost efficiency. Therefore, the adoption of advanced ICT enhances tourism firms' growth opportunities through reducing information asymmetry and agency costs (Chen et al., 2018). Given that tourism firms' performance and ICT infrastructure are closely connected, tourism firms have been encouraged to adopt the right ICT infrastructure to efficiently direct and manage their operations in order to help them provide competitive prices and thereby enhance their performance (Madhukar and Sharma, 2019), and consequently develop the tourism sector as a whole.

The improvement of ITC infrastructure also contributes to developing the tourism sector by providing tourists, and tourism-related businesses with necessary information and appropriate applications. In this vine, the internet, computer, and mobile technologies provide current and potential tourists with quick, direct and cheap information on destinations such as touristic landmarks, economic stance, security position, accommodation, transport, and any other related information. As a result, the number of incoming tourists coming would increase and thereby improve the development of the sector. In addition, advanced ICT offers tourism applications that have enabled tourists to plan all transactions related to their programs online, including booking tickets and hotels, travel insurance and other related transactions (Tan et al.,2017; Law et al.,2018). For example, mobile technology through mobile devices enhance transactions and provides guides on tourism transactions (Ukpabi and Karjaluoto, 2017), where 60\% of global smart phone users download travel apps onto their devices with $45 \%$ of them using these apps regularly to plan transactions related to their touristic programs (Good Work Labs, 2016). As a result, tourism applications not only deliver appropriate advantages in terms of easy cancellations, modified offers, a secure payment platform, planning and research but they also deliver other advantages that save time and costs, such as comparative pricing and access to the best offers at lower prices (Madhukar and Sharma, 2019). Furthermore, utilizing advanced ICT infrastructure, in particular the internet, increases the online presence of a tourist destination, making it competitive in the global market by providing online applications that facilitate the work of tourist agencies and other related tourism businesses (Adeola and Evans, 2020).

This would efficiently promote domestic tourism in the global market, increasing the demand for tourism services and eventually enhance the sector's development. The deployment of mobile technology has fundamentally transformed what tourism is offering. In light of the above, tourism has become an information-intensive business that relies on ICT to provide information and conduct transactions for consumers of touristic products and services via internationally available applications (Gretzel et al., 2015). Thus, it is not surprising that ICT infrastructure has played an important role in developing the tourism sector (Gössling, 2021). For example, leading online travel companies like Booking Holdings and the Expedia Group made worldwide revenues of 15.07 billion and 12.07 billion US dollars respectively in 2019 (Statistics, 2019). Empirical evidence by Adeola, and Evans (2020), found that the increase of ICT by 1 unit leads to increasing tourism demand by 1.5 units. This indicates that the higher scale of ICT, the greater the number of tourist arrivals, implying that ICT significantly improves the level of the tourism sector.

Although, African countries have sought to adopt advanced ICT due to its potential to ameliorate tourism sector development (Ukpabi and Karjaluoto, 2017; Ankomah and Larson, 2019), The spared of ICT across the African continent had only increased in the late 2000s and early 2010s, (Ponelis and Holmner, 2015). It was only in the beginning of 2000s, that the internet became more commonplace in African households (Beda, 2019). In particular, the individual use of the internet in top 10 Africa countries have gradually progressed over the first decade of millennium (See the graph below). For example, the percentage of individual using the internet per hundred inhabitants in Botswana was $3.3 \%$ in $2004,6 \%$ in 2010, and substantially reached to $47 \%$ in 2017, in Egypt this figure was $11.9 \%$ in 2004 , $21.6 \%$ in 2010, and remarkably increased to $44.95 \%$ in 2017, in Kenya was $3.02 \%$ in 2004, 7.20\% in 2010, and modestly increased to $17.8 \%$ in 2017 comparatively to Botswana and Egypt, in Morocco was 11.16\% in 2004, increasing to 52\% in 2010, and 61.76\% in 2017 (International Telecommunication Union's World indicator, Statistics, 2017). Nevertheless, the level of African countries' ICT infrastructure in particular is still lower comparatively to their counterparts in developed countries. For example, individuals using the internet in developed countries is substantially higher, in the USA, for example, the figure was $64.67 \%$ in $2004,71.69 \%$ in 2010 , and substantially reached to $87.27 \%$ in 2017, in France was 39.15\%,77.28\% in 2010, and 80.50\% in 2017 (International Telecommunication Union's, World indicator, Statistics, 2017). Moreover, the level of development in ICT infrastructure in African countries have not reached the desired level to meaningfully affect competitiveness of the regions' tourism sector (Wamboy et al., 2020), which in turn may influence the level of tourism sector development in those countries. Based on above this study proposes that the relationship between ICT infrastructure and tourism development in Africa is non-linear and there by attempts to answer the following question: what is the threshold for ICT infrastructure to meaningfully contribute to the development of the tourism sector in the 10 top African destinations? In investigating this area, this paper aims to empirically investigate the threshold effect of ICT infrastructure on tourism sector development by focusing specifically on Botswana, Egypt, Kenya, Namibia, Morocco, Rwanda, South Africa, Tanzania, Tunisia, Uganda during the period 2004-2017. Understanding the effect of ICT infrastructure including Internet usage by individuals, fixed broadband subscriptions, and broadband Internet connection via home computer in those countries will help tourism industry policy makers design policies, strategies, and programs that could maximize the benefits from that develop the tourism sector. The effect of ICT infrastructure on developing tourism sector has not fully and empirically been investigated. 
The only study that has empirically studied the effect ICT infrastructure on tourism sector development carried out by Adeola, and Evans, (2020) which focused on the effect of ICT infrastructure on the number of intentional tourist arrivals in African countries. Thus, this paper contributes to literature in two main ways. First, it expands the literature's scope on the effect of ICT infrastructure on tourism sector development by investigating the threshold effect of ICT infrastructure on tourism sector development in top 10 African tourism destinations Second, this paper will provide comprehensive empirical evidence on the relationship between ICT infrastructure and the development of tourism sector by including the effect of ICT infrastructure on international tourist arrivals and international tourism receipts.

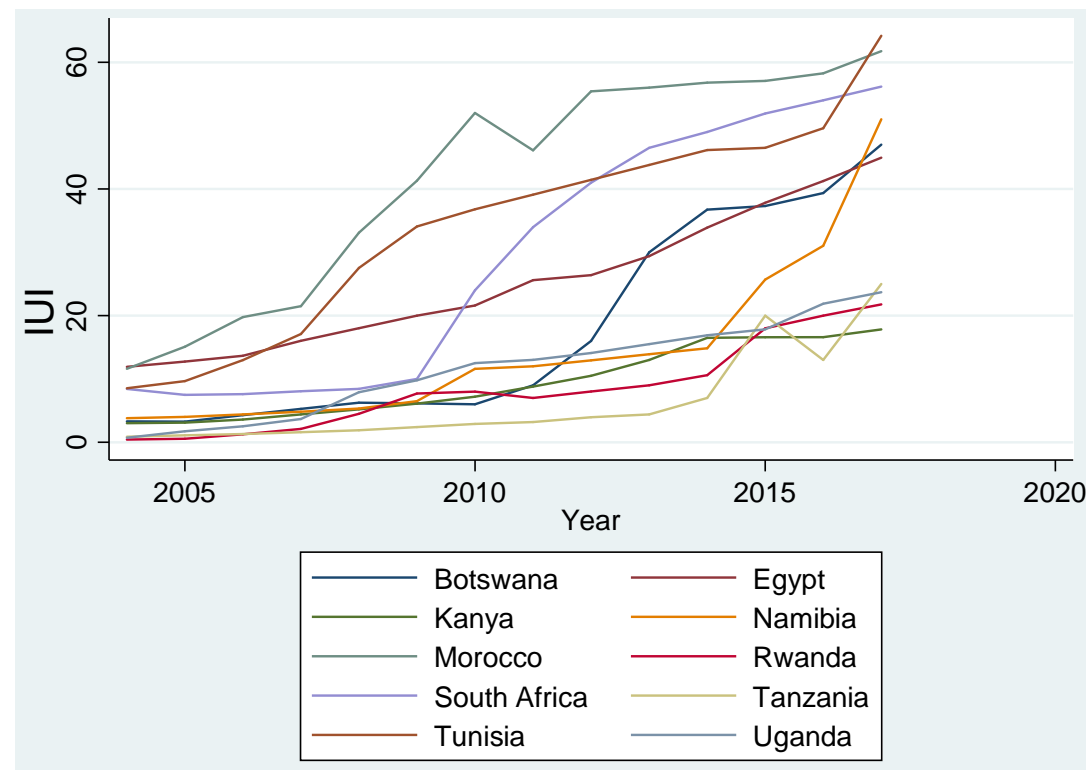

Figure 1. Individual use of internet as percentage of population in top 10 African destinations

\section{LITERATURE REVIEWS}

1. Effect of macroeconomic variables on the development of the tourism sector

2.1. Effect of gross domestic product on tourism sector development

Several studies have addressed the relationship between tourism sector development and the level of aggregate economic activity. For example, Nemec Rudez (2008) examined the impact of GDP on international tourism expenditures in Slovenia. He found out that GDP has positive and strong impact on international tourism expenditure in Slovenia. Further, he indicated that income elasticity of outbound tourism falls when GDP increases. This results signifies higher level of GDP leads to slight change in tourism demand, indicating that foreign destinations on average are considered as luxury destinations for Slovenian tourists.

Also, Martins and Ferreira-Lopes,

(2017) examined the effect of economic activity on tourism demand. They found that the World's GDP per capita, is the driving force among the macroeconomic variables that stimulates the number of international tourist arrivals. In the same way, Shahbaz et al., (2017) confirmed that GDP per capita in Malaysia stimulates tourism demand by increasing the number of international tourist arrivals and international tourism receipts. More recently, Rasool et al. (2021) investigated the relationship between tourism development and economic growth in BRICS countries and concluded that international tourism receipts per capita and economic growth are co-integrated and have long relationship.

Also, they found out a bi-directional causal relationship between international tourism receipt per capita and economic growth which therefore back up both the tourism-led growth hypothesis, and the economic-driven tourism growth hypothesis. Consequently, tourism sector is not only the driving force for economic growth, but the economic growth itself can contribute in developing tourism sector in BRICS countries.

\subsection{Effect of exchange rate on tourism sector development}

Another standard of literature have concentrated on the effect of exchange rate on tourism development as one of the most important factors influencing tourism industry, as it directly affects tourism companies' costs and revenues. Changes in foreign exchange can lead potential travelers to change their destinations or reduce the length of the holidays, both of which result in revenue loss to the host country's economies (Webber, 2001). However, the empirical studies have not reached to the same conclusion on the effect of exchange rate on tourism demand. Some studies have found out positive effect, negative effects, others found no effect. For example, Surugiu et al. (2011), Vita et al. (2013), Khoshnevis et al. (2017), showed that exchange rate had a negative impact on the international tourism demand in the case of Romania, Turkey, and the USA respectively. However, Quadri and Zheng (2010) analyzed the relationship between exchange rates and international arrivals of 19 host countries in the case of Italy.

The impacts only had the statistical significance in 8 countries, while exchange rates were found to be irrelevant with international tourist arrivals in eleven of the nineteen countries. Martins et al., (2017) indicated that the decline in the nominal exchange rate of the origin country against the tourist destination country could increase tourism demand by tourists from the origin country's as long as the level of prices in the tourist destination country relatively lesser than those in tourist origin country. Contrary, if the level of prices in the tourist destination country is higher than the origin country, the more likely it is for the number of tourists coming from the origin country to the tourist destination to the tourist destination country to decrease. Tung (2019) argued that devaluation of domestic currency has positive effect on the number of foreign tourists to Vietnam indicating that as the Dong exchange rate against the USA dollar increase, foreign tourists look for to other touristic destinations causing a decline in the number of foreign tourists coming to Vietnam. Sharma et al. (2019) also, found that number of foreign tourist arrivals in India is negatively affected by exchange rates in both the long and short-term, with greater impact in the short-term. 


\subsection{Effect of inflation on tourism sector development}

Several studies have paid attention to the effect of inflation on tourism development. In this aspect (Salman, 2003; Lim, 2004; Dritsakis, 2004; Toh et al., 2006). Indicated that as the level of prices increase, the number of international tourist arrivals declines, indicating that inflation has a negative impact on the development of tourism sector. Saayman, and Saayman (2015) showed how tourist expenditure by international tourists in South Africa response to relative price in origin destinations as well as in competitor destinations. Results indicated the elasticity of tourist expenditure by tourists in South Africa with respect to relative price of origin destinations (Australia, Brazil, France, Germany, India, Netherlands, UK, and USA, was inelastic expect for Netherland. Therefore, tourist expenditure decrease by less than the increase in the relative price expect for Netherland. Furthermore, the substitute price elasticity was positive indicating that tourism destinations including Botswana, Kenya and Tanzania, are considered as international tourism destination substitutes to South Africa. Therefore, if prices in South Africa increases relatively to those destinations, the tourist spending in South Africa may declines, with more tourists spending money in alternative destinations. Finally, Martins and Ferreira-Lopes, (2017) pointed out that a decline of relative domestic prices do help boost tourism demand as measured by the number of international tourist arrivals, but relative prices become more important in affecting tourism demand when the international tourist expenditures is employed as the proxy for tourism demand.

\subsection{Effect of financial development on tourism sector development}

A limited number of studies have considered the role of financial development in deriving tourism sector development. For example, with a focus on India, Ohlan (2017), found that there is a long-term link between tourism and various financial development. Shahbaz et al. (2017) highlight that the Granger causality test shows bi-directional causation between financial development and tourism. They also, found that there is also a long-term link with the development of the tourism sector (foreign tourist arrivals and tourist receipts). Furthermore, they indicated that financial development positively affects tourist development in the long-term. Katircioglu et al. (2018) confirmed the existence of a long-term association between financial and tourist development, which can be attributed to the pecking order theory: better financial and market conditions will attract tourism entrepreneurship because firms will be able to use more capital instead of being forced to use leveraging. Yenisehirlioglu and Bayat (2019) investigated whether there is a causal relationship between tourism development and financial development in the MENA countries. They found out a unidirectional causal relationship running from financial development to tourism development in Jordan and Tunisia. Whereas, in Sudan and Morocco a unidirectional causal relationship was found from tourism development to financial development. In addition, Musakwa, and Odhiambo, (2020) investigated the causal link between financial development and tourism development in South Africa. They pointed out that the causal link between the two depends on the proxy being used for financial development. In the sense that a unidirectional causality link was existed in the short and the long- run from tourism development to financial development when broad money was employed to represent financial development. Whereas, a bidirectional causal link was found between them in the short -run, but a unidirectional causal link from financial development to tourism development was found to in the longrun when the domestic credit provided by financial sector was used to account for financial development.

\section{Effect of ICT infrastructure on tourism sector development}

A number of studies have indicated that ICT plays an important role in influencing the development of the tourism industry. Ma et al., (2003) examined how the development of ICT, particularly the internet, have transformed the Chinese tourism industry. They indicated that despite the development of ICT in China, Chinese business had not seen as much benefit as had been expected from the internet. Most tourism-related businesses in China still conduct their operations in traditional way with little application of an information network. Also, Bethapudi, (2013) and Firoiu and Croitoru (2013), point out that ICT has an essential role in developing and expanding the tourism industry's activities as ICT facilitates reaching tourism products and services by targeting customers across the globe, especially after the emergence of web technologies via mobile computers. All studies on the impact of ICT on the tourism industry have empirically ignored the effect of ICT on tourism development. The one exception to this is Adeola and Evans (2020), who found that ICT positively influences the number of intentional tourist arrivals in Africa. This paper seeks to expand the existing literature on this perspective by investigating the threshold effect of ICT infrastructure on tourism industry's development by focusing on the top 10 African tourism destinations. Moreover, Kumar and Kumar, (2020) studied the association between ICT infrastructure and tourism demand in major tourist destinations namely; China, France, Germany, Italy, Mexico, Russia, Spain, the United Kingdom, and the United States. They indicated that mobile subscriptions and broadband positively and strongly derive international tourist arrivals in both short and long-runs.

\section{DATA AND METHODOLOGY}

\section{Data}

As mentioned above, this paper investigates the effect of ITC infrastructure on the development of the tourism sector in related to the top 10 African tourism destinations. To achieve this, yearly data covering the period from 2004 to 2017 will be employed. The start and end point for data duration was chosen based on the availability of data, with the 2004 starting date the result of the fact that some ITC infrastructure proxies, namely fixed broadband subscriptions (per 100 people), have been available in all countries since 2004. In the same way, the end date of 2017 was due to the availability of data related to dependent variables until this year. For example, data on international tourist arrivals, and international tourism receipts in Kenya and Botswana are available until 2017. Also, data on some independent variables, like the number of individuals using the Internet (\% of population) are available up to 2017 in Botswana, Kenya, Namibia, South Africa, Rwanda, and Uganda. 


\section{Dependent variables}

The dependent variable in this study is the development of the tourism sector which is represented by two indicators, namely, international tourist arrivals (ITA) and international tourism receipts (ITR) since the World Tourism Organization (UNWTO) considers these two indicators as important in gauging tourism development (Koçak et al., 2020). Furthermore, previous studies (e.g. Lee and Brahmasrene, 2013; Naradda Gamage et al., 2017) have concentrated on these as proxies for development in the sector, and they took them into account to represent the sector's development. Data on $I T A$ and $I T R$ was taken from World Bank data.

\section{Independent variables}

The key independent variable in this study is ICT infrastructure in the African countries that were the top 10 most popular destinations for tourists in the period 2004-2017. Existing literature (e.g.Toader et al., 2018; Bahrini and Qaffas, 2019) has used different proxies for ICT, including mobile cellular subscriptions per 100 people (MCS), the number of fixed telephone subscriptions per 100 people (FTS), the individual use of internet as percentage of population (IUI) ,and the number of fixed broadband subscriptions per 100 people (FBS). However, those proxies are at most highly correlated, as is shown in Table (1), and hence using them all or some of them in one model will rise multicollinearity problem. The influence of control variables on the tourism sector's development will also be taken into account following previous studies by including; gross domestic product (GDP), inflation rate presented by the growth rate of consumer price index (CPI), real exchange rate (RER) computed as nominal exchange rate (country inflation rate)/ the USA inflation rate), banking sector's development is proxied by credit to the private sector (CPS). Data on ICT infrastructure, as well as, data on macroeconomic variables were obtained from the World Bank's database. To overcome the multicollinearity problem related to MSC,FTS,IUI, and FBS, an index of ICT infrastructure (ICTIND) is constructed based on MSC,FTS, IUI, and FBS employing principle component analyses following (Adeola and Evans, 2020). Therefore, in this study the 10 most popular African tourist destinations represent the ICT infrastructure variable. Table (2) shows the principal component analysis results where the first principal component account for $71.8 \%$ of the variation, while the second, third and fourth explain only $16.6 \%, 7.9 \%$, and, $3.7 \%$ of the variation respectively. Consequently, the first principal component is the best representative of ICTIND that constructed from MSC, FTS, IUI , and FBS.Table (3) shows each variable statistical descriptions.

Table 1. Correlation matrix among independent variables

\begin{tabular}{|c|l|l|l|l|l|l|l|l|}
\hline Correlation & $C P I$ & $D C P$ & GDP & RER & FTS & FBS & MCS & IUI \\
\hline CPI & 1 & & & & & & & \\
\hline$D C P$ & -0.013 & 1 & & & & & & \\
\hline GDP & 0.215 & 0.551 & 1 & & & & & \\
\hline RER & 0.111 & -0.460 & -0.290 & 1 & & & & \\
\hline FTS & -0.163 & 0.602 & 0.440 & -0.614 & 1 & & & \\
\hline FBS & 0.398 & 0.434 & 0.312 & -0.637 & 0.781 & 1 & & \\
\hline MCS & 0.568 & 0.533 & 0.377 & -0.379 & 0.719 & 0.687 & 1 & \\
\hline IUI & 0.482 & 0.535 & 0.385 & -0.283 & 0.663 & 0.826 & 0.781 & 1 \\
\hline
\end{tabular}

Table 2. Principal component analysis for ICTIND

\begin{tabular}{|c|c|c|c|c|}
\hline & PCA 1 & PCA 2 & PCA 4 & PCA 4 \\
\hline Eigenvalues & 2.87 & 0.664 & 0.316 & 0.148 \\
\hline \% of variance & 0.718 & 0.166 & 0.079 & 0.037 \\
\hline Cumulative & 0.718 & 0.884 & 0.963 & 1 \\
\hline Variables & Vector 1 & Vector 2 & Vector 3 & Vector 4 \\
\hline MCS & 0.518 & -0.191 & 0.769 & 0.318 \\
\hline FTS & 0.391 & 0.917 & 0.004 & -0.074 \\
\hline FBS & 0.531 & -0.180 & -0.626 & 0.541 \\
\hline IUI & 0.543 & -0.299 & -0.125 & -0.077 \\
\hline
\end{tabular}

Note: PCA: principal component analysis; Vector: Eigenvectors

\section{Methodology}

This study proposes that the impact of ICT infrastructure on the tourism sector, in terms of the top 10 African tourist destinations, may be non-linear. In the sense that, African countries have devoted their efforts to adopt advanced ICT to ameliorate the level of tourism sector development (Ukpabi and Karjaluoto, 2017). Also, the spread of ICT across the African continent had only begun in the late 2000s, and increased in early 2010s (Ponelis and Holmner, 2015 and Beda, 2019). Therefore, this study suggests that ICT infrastructure has different impacts on the development of the tourism sector through the influence of different critical values of ICT infrastructure on development of the tourism sector. In other words, this study employs on threshold regression model in providing empirical evidence on the impact of certain values of ICT infrastructure ICT infrastructure on tourism sector development. More specifically, this study utilizes a panel threshold regression model (Hansen, 1999) using yearly data during the period 2004-2017 following Liu, and Fan (2020). In this paper, the panel threshold regression model implies that the response of the tourism sector to ICT infrastructure change is different under different ICT infrastructure levels. For example, when the ICT infrastructure exceeds a critical value, the sign or the magnitude of the ICT infrastructure coefficient significantly changes and thereby, the benefits from ICT infrastructure can be maximized in order to improve the level of tourism sector's development. The panel threshold model (Hansen, 1999) is set as follows:

$$
Y_{i t}=u_{i}+B_{0}^{s} z_{i t}+B_{1}^{s} x_{i t} I\left(q_{i t} \leq \gamma\right)+B_{2}^{s} x_{i t} I\left(q_{i t}>\gamma\right)+e_{i t}
$$

This study utilizes a panel threshold model to estimate equation (1) based on the variables explained above. Therefore, if a single panel threshold model is used, the equation (1) needs to be rewritten in the following way:

$Y_{\text {it }}=u_{i}+B_{0}^{s} z_{\text {it }}+B_{1}^{s} x_{i t} I\left(q_{\text {it }} \leq \gamma_{1}\right)+B_{2}^{s} x_{\text {it }} I\left(q_{\text {it }}>\gamma_{1}\right)+e_{\text {it }}$

While, if a double panel threshold model is used, the equation (1) needs to be rewritten as follows:

$$
Y_{\text {it }}=u_{i}+B_{0}^{s} z_{\text {it }}+B_{1}^{s} x_{\text {it }} I\left(q_{\text {it }} \leq \gamma_{1}\right)+B_{2}^{s} x_{\text {it }} I\left(\gamma_{1}<q_{\text {it }} \leq \gamma_{2}\right)+B_{a}^{s} x_{i t} I\left(q_{\text {it }}>\gamma_{1}\right)+e_{\text {it }}
$$


Where: $Y_{\text {it }}$ is the dependent variable which represented by international tourist arrivals (ITA) and, international tourism receipts $(I T R), u_{\mathrm{i}}$ is the constant term, $z_{\mathrm{it}}$ is a set of control variables including; gross domistic product (GDP), consumer price index (CPI), Real exchange rate (RER), credit to the private sector $(C P S), x_{i t}$ is the main independent variable represented by information thechnology infrastructure index(ICTIND), $q_{\text {it }}$ signifies the threshold variable which is information thechnology infrastructure index (ICTIND), $\gamma$ is the threshold value to be computed, $\gamma_{1}, \gamma_{2}$ are the first and second threshold variables respectively to be estimated, $e_{\text {itt }}$ represents the error term, $I($.$) is the indicative function, that takes the$ value of 1 if the conditions in the parentheses are correct and 0 if the conditions in the parentheses are not established, $B_{0}, B_{1}$, $B_{2}$ are the variables' coefficients to be estimated for each variable, $i$ represents the country, and $t$ stands for years.

Table 3. Variables descriptive statistics

\begin{tabular}{|c|c|c|c|c|c|}
\hline Variable & Mean & Std. Dev & Min & Max & Obs. \\
\hline CPI & 106.27 & 31.097 & 50.335 & 231.094 & 140 \\
\hline DCP & 47.47 & 40.119 & 7.107 & 160.124 & 140 \\
\hline GDP & $8.61 \mathrm{E}+10$ & $1.16 \mathrm{E}+10$ & $3.54 \mathrm{E}+09$ & $4.26 \mathrm{E}+11$ & 140 \\
\hline RER & 479.198 & 856.116 & 1.232 & 3692.242 & 140 \\
\hline$I T R$ & $3.41 \mathrm{E}+09$ & $3.47 \mathrm{E}+09$ & $4.40 \mathrm{E}+07$ & $1.36 \mathrm{E}+10$ & 140 \\
\hline$I T A$ & 4050919 & 3807881 & 421000 & $1.41 \mathrm{E}+07$ & 140 \\
\hline MCS & 73.748 & 43.156 & 1.581 & 163.875 & 140 \\
\hline FTS & 5.508 & 4.476 & 0.102 & 14.883 & 140 \\
\hline FBS & 1.173 & 1.551 & 0.001 & 7.012 & 140 \\
\hline ICTIND & 0.787 & 1 & -0.755 & 3.764 & 140 \\
\hline
\end{tabular}

Table 4. Threshold effect test

\begin{tabular}{|c|c|c|c|c|c|}
\hline & \multicolumn{5}{|c|}{ Test for threshold effect } \\
\hline & ICTIND based on ITA \\
\hline $\begin{array}{c}\text { Type of } \\
\text { threshold model }\end{array}$ & F-value & P-value & $1 \%$ & $5 \%$ & $10 \%$ \\
\hline $\begin{array}{c}\text { Single threshold } \\
\text { model }\end{array}$ & $15.256^{* * *}$ & 0.145 & 14.365 & 12.254 & 11.968 \\
\hline $\begin{array}{c}\text { Double threshold } \\
\text { model }\end{array}$ & $20.234^{* * *}$ & 0.000 & 15.123 & 12.365 & 9.235 \\
\hline $\begin{array}{c}\text { Triple-threshold } \\
\text { model }\end{array}$ & 0.125 & 0.958 & 0.265 & 0.221 & 0.187 \\
\hline $\begin{array}{c}\text { Test for threshold effect } \\
\text { of ICTIND based on ITR }\end{array}$ \\
\hline $\begin{array}{c}\text { Single threshold } \\
\text { model }\end{array}$ & 10.136 & 0.165 & 9.369 & 8.357 & 8.985 \\
\hline $\begin{array}{c}\text { Double threshold } \\
\text { model }\end{array}$ & $35.236 * *$ & 0.000 & 25.358 & 21.369 & 19.968 \\
\hline $\begin{array}{c}\text { Triple-threshold } \\
\text { model }\end{array}$ & 0.000 & 0.145 & 0.010 & 0.047 & 0.087 \\
\hline
\end{tabular}

Note $:^{*, * *, * * *}$ indicate the coefficient that are significant at $1 \%, 5 \%, 10 \%$ levels respectively

Table 5. Threshold value estimates

\begin{tabular}{|c|c|c|}
\hline & \multicolumn{2}{|c|}{$\begin{array}{c}\text { Estimating threshold value of } \\
\text { ICTIND based on } \boldsymbol{I T A}\end{array}$} \\
\hline Threshold value & \multicolumn{2}{|c|}{$95 \%$ Confident intervals } \\
\hline$\left(\gamma_{1}\right)$ & $(0.392,0.410)$ & 0.401 \\
\hline$\left(\gamma_{2}\right)$ & $(1.452,1.501)$ & 1.512 \\
\hline & \multicolumn{2}{|c|}{$\begin{array}{c}\text { Estimating threshold value of } \\
\text { ICTIND based on } \boldsymbol{I T R}\end{array}$} \\
\hline Threshold value & \multicolumn{3}{|c|}{ 95\% Confident intervals } \\
\hline$\left(\gamma_{1}\right)$ & $(0.332,0.361)$ & 0.359 \\
\hline$\left(\gamma_{2}\right)$ & $(1.412,1.453)$ & 1.442 \\
\hline
\end{tabular}

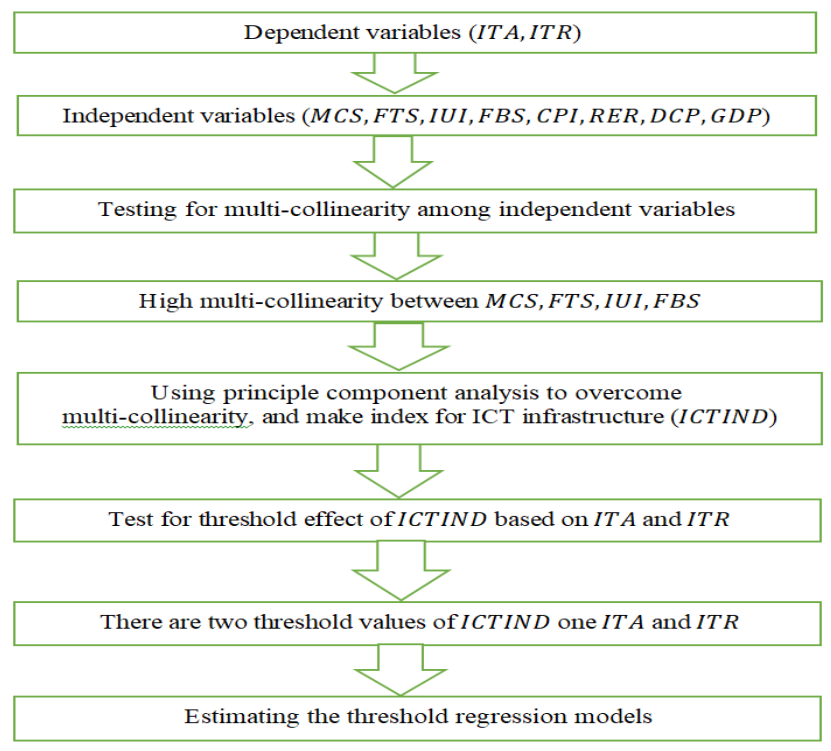

Figure 2. The study's methodology

Table 6. Threshold regression model results

\begin{tabular}{|l|l|}
\hline \multicolumn{1}{|c|}{ Constant } & \multicolumn{1}{c|}{ Model 4 } \\
\hline CPI & 0.501 \\
\hline DCP & $-0.988^{*}$ \\
\hline GDP & $0.358^{* *}$ \\
\hline RER & $0.994^{* *}$ \\
\hline ICTIND $\leq 0.251$ & $-1.135^{* * *}$ \\
\hline $0.251<$ ICTIND $\leq 1.412$ & $0.052^{*}$ \\
\hline ICTIND>1.412 & $1.298^{* * *}$ \\
\hline F - test & 1.987 \\
\hline$R^{2}$ & $95.145^{* * *}$ \\
\hline Obs. & $68.451 \%$ \\
\hline Variables & 140 \\
\hline Constant & Model 5 \\
\hline CPI & 0.189 \\
\hline DCP & $-1.205^{* * * *}$ \\
\hline GDP & 0.712 \\
\hline RER & $0.662^{* *}$ \\
\hline ICTIND $\leq 0.299$ & $-1.458^{* * *}$ \\
\hline $0.299<$ ICTIND $\leq 1.463$ & $0.078^{* *}$ \\
\hline ICTIND 1.463 & $0.741^{* * *}$ \\
\hline F - test & 0.914 \\
\hline$R^{2}$ & $83.1259^{* * *}$ \\
\hline Obs. & $55.101 \%$ \\
\hline & 140 \\
\hline
\end{tabular}

Note: Model 4,and model 5represent the effect of ICTIND on $I T A$ and $I T R$ respectively, ${ }^{*}, *, * * *$ indicate that coefficient that are significant at $1 \%, 5 \%, 10 \%$ levels respectively

\section{EMPIRICAL ANALYSIS}

\section{Testing and estimating threshold values}

The adoption of double panel threshold model or a single panel threshold model depends on the statistical significance of the number of threshold values being estimated. This study attempts to test for a double threshold model, and thereby the model (3) can be rewritten and estimated as follows: 


$$
\begin{aligned}
& I T A_{\text {it }}=u_{1}+B_{1} G D P_{\mathrm{i}, \mathrm{t}}+B_{2} C P I+B_{2} R E R+B_{4} C P I+B_{5} I C T I N D_{\text {it }} I\left(q_{\text {it }} \leq \gamma_{1}\right)+B_{6} I C T I N D_{\text {it }} I \quad\left(\gamma_{1}<q_{\text {it }} \leq \gamma_{2}\right)+ \\
& B_{7} I C T I N D_{\text {it }} I\left(q_{\text {it }}>\gamma_{1}\right)+e_{\text {it }} \\
& I T R_{\text {it }}=u_{i}+B_{1} G D P_{1,5}+B_{2} C P I+B_{2} R E R+B_{4} C P I+B_{5} I C T I N D_{i t} I\left(q_{\text {it }} \leq \gamma_{1}\right)+B_{6} I C T I N D_{i t} I \quad\left(\gamma_{1}<q_{\text {it }} \leq \gamma_{2}\right)+ \\
& B_{7} I C T I N D_{\text {it }} I\left(q_{\text {it }}>\gamma_{1}\right)+e_{\text {it }}
\end{aligned}
$$

Where: $I T A$ is international tourist arrivals, $I T R$ is international tourism receipts, $u_{i}$ is the constant term, gross domistic product, CPI consumer price index, RER is Real exchange rate, CPS is credit to the private sector, ICTIND information thechnology infrastructure index, $q_{\text {it }}$ signifies the threshold variable which is information thechnology infrastructure index ,(ICTIND), $\gamma_{1}, \gamma_{2}$ are the first and second threshold variables respectively to be estimated,

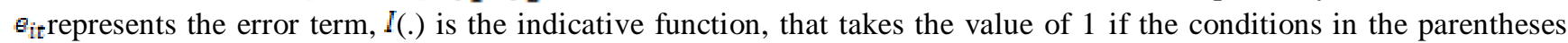
are correct and 0 if the conditions in the parentheses are not established, $B_{0}, B_{1}, B_{2} B_{3}, B_{4}, B_{5}, B_{6}, B_{7}$ are the variables' coefficients to be estimated for each variable, $i$ represents the country, and $t$ stands for years.

Models 4 and 5 estimated by repeating data 500 times utilizing a bootstrap method to estimate the $F$ and p-value. Based on model (4) and (5) there are three scenarios: the first scenario when neither the first threshold $\gamma_{1}$ nor the second threshold $\gamma_{2}$ are statically significant implying that the model has no thresholds; the second scenario when model has one threshold if $\gamma_{1}$ is statically significance and $\gamma_{2}$ is not, the third scenario is the model has two thresholds if both $\gamma_{1}$ and $\gamma_{2}$ are statically significant. Table (3) shows the number of threshold values for the threshold models of ITA and ITR as per of ICTIND. Results indicate that information thechnology infrastructure index ICTIND has two threshold values for both ITA and ITR threshold models since the p-value of both single threshold $\left(\mathrm{\gamma}_{1}\right)$ and the double threshold $\left(\mathrm{\gamma}_{2}\right)$ are significant at the $1 \%$ level of significance. After confirming existence of two threshold values $\left(\gamma_{1}, \gamma_{2}\right)$, those two threshold values should be estimated based on the number of thresholds.

Table 5 shows the estimated threshold value results. According to the estimated threshold values shown in Table 5, model (4) and model (5) are classified into three segments. The first segment is when the level of threshold variable is lower than the first threshold value. The second segment is when the level of threshold variable is higher than the first threshold value but lower than the second threshold value. The third segment is when the level of threshold variable is higher than the second. After confirming the existence of two threshold values, the relation between the threshold effect of the ICT infrastructure and tourism sector development must be examined by regressing ICTIND first on ITA and second on ITR. Thereafter, the different impacts of the two threshold values of ICTIND on ITA and ITR must be compared to determine the economic meaning of those threshold values.

\section{The threshold regression results}

This study aims to investigate the threshold effect of ICT infrastructure on the tourism sector's development in the top 10 African tourism destinations utilizing double panel threshold model that employs as the threshold variable. Results of double panel threshold model are displayed in Table 6 based on model 4 and model 5 which indicate that the effect of ICT infrastructure on the tourism sector's development in the top 10 African tourism destinations is not the same and varies according to the threshold values. Therefore, the relationship between, and is non-linear and the benefits of ICT infrastructure can be maximized to develop the tourism sector in the destinations mentioned.

This result is in accordance with Adeola and Evans, (2019) who indicated that the effect of mobile penetration, internet usage on tourism development is non-linear in African countries. More specifically, they pointed out that mobile penetration and internet usage significantly and negatively derive the number of international tourist arrivals only to a certain point, after which they significantly and positively influence international tourist arrivals. Model 4 in Table 6 is dedicated to investigate the threshold effect of ICT infrastructure on ITA in top 10 African tourism destinations.

According to Table 6 when the level of ICTIND is equal or lower than the first threshold value (ICTIND $\leq 0.251)$, the ICTIND has significantly marginal and weaker positive effect on ITA. This result implies that when the level of ICTIND is lower than the first threshold value, the tourism destinations cannot effectively maximize the benefits from investing in ICT infrastructure to enhance the number of international tourist arrivals. In other words, when the level of ICTIND is too low,the response of ITA to ICTIND changes has not been in the desired level, and thereby supporting and leading role of ICT infrastructure has not been fully mobilized to develop the touristic sector in destinations analyzed. However, When the level of ICTIND is higher than the first threshold value but lower than the second threshold value $(0.251<I C T I N D \leq 1.412)$, the ICTIND has the dominant impact on ITA and also, the impact of ICTIND on ITA remains significantly positive but the magnitude effect has remarkably and strongly increased.

This implies that the tourism destinations can maximized the benefits from ICT infrastructure to effectively improve the level of their development by increasing investment in this area. However, when the level of ICTIND is above the second threshold (ICTIND> 1.412), the effect of ICTIND on ITA is no longer positively and strongly significant, indicating that ICTIND level of the majority of the top 10 African destinations have not yet reached the level above 1.412. In this regard, the level of ICTIND in destinations like Botswana, Kenya, South Africa, Tanzania, Rwanda Namibia, and Uganda has reached an upper limit of 1.006, 0.386, 1.260, 0.144, $0.636,1.008$, and 0.606 respectively. However, the level of ICTIND has exceeded the level of 1.412 only in three destinations namely, Egypt, Morocco, and Tunisia with ICTIND level of 2.741, 1.741 and 3.764 respectively. This result is in line with Liu and Fan, (2020) pointed out that the effect of international technology spillovers on China's economic growth is nonlinear, that is, when 
international technology factors are between the two threshold values, the benefits from international technology spillovers in enhancing China's economic growth are maximized. In the same way, the effect of ICT infrastructure on $I T R$ is non-linear and varies according to the level of ICT infrastructure. Table 6 shows that $I T R$ responses differently to changes in ICTIND levels, where the response shifts from weakly negative into strongly positive as the level of ICTIND increases. More specifically, when the level of ICTIND is equal or lower than the first threshold value (ICTIND $\leq$ 0.299 ), the ITR positively and weakly response to ICT infrastructure.

This result implies that when the level of ICTIND is lower 0.229, the tourism destinations cannot enhance the magnitude of international tourism receipts because at this level of ICTIND the tourism destinations cannot effectively maximize the benefits from investing in ICT infrastructure to enhance the number of international tourist arrivals. Whereas, when the level of ICTIND is higher than the first threshold value but lower than the second threshold value $(0.299<I C T I N D \leq 1.463)$, the $I T R$ remarkably an strongly responses to ICTIND, indicating that top 10 African destinations can maximize the benefits from ICT infrastructure to increases the magnitude of $I T R$.

However, when the level of ICTIND is above the second threshold (ICTIND > 1.463), the response of ITR to ICTIND is relatively higher but not statistically significant, indicating that ICTIND level of the majority of the top 10 African destinations have not yet reached the level above 1.463. Therfore, tourism destinations must enhance the magnitude of investment in ICT infrastructure to enhance the magnitude of international tourist receipts.

It is noteworthy that ITR is remarkably and substantially affected by the level of inflation and exchange rate not by the magnitude of ICT infrastructure as ITA. This may due to the fact that tourism expenditure is more likely to be highly affected by the level of prices represented by the level of inflation and exchange rate reflecting that $I T R$ is highly affected by the level of inflation and exchange rate. In this aspect, Saayman and Saayman, (2015) indicated that if the level of prices in the origin destination (South Africa) increases relatively to alternative destinations (Botswana, Kenya, Tanzania) the tourist spending in origin destination declines, with more tourists spending money in alternative destinations. Consequently, ITR tends to substantially decreases in response to inflation level changes.

\section{CONCLUSION}

In this paper, we propose a double panel threshold model to investigate whether ICT infrastructure has had a threshold effect on tourism sector development in top 10 African tourism destinations during the period 2004 to 2017.The results show the ICT infrastructure has had a threshold effect on tourism sector development in top 10 African countries signifying that this effect of ICT infrastructure on tourism sector development is non-linear and varies according to the level of ICT infrastructure. More specifically, when the ICTIND level is employed as a threshold variable, the response of both ITAand ITR to changes in ICTIND shift from weakly positive into strongly positive response as the level of ICTIND increases, indicating that ICT infrastructure has a non-linear consistent effect on both measures of tourism sector development in Top 10 tourism destinations. In particular, (1) when ICTIND level is below 0.251 , the ICTIND will have a positive weak effect on ITA. When the level of ICTIND is higher than 0.215, but lower than 1.412, the positive weak effect of the ICTIND on tourism development will be turn out to a strong positive effect. When the level of ICTIND is higher than 1.412, the ICTIND will be irrelevant on ITA. This conclusion indicates that the ICT infrastructure is not conducive to ITA in countries with low ICT infrastructure levels. On the contrary, in countries with high ICT infrastructure levels will increase ITA. (2) On the same way, ITR has the same pattern response to ICTIND as ITA did but different in the magnitude. When ICTIND level is below0.299, the ITR will have a positive weak response on ICTIND. When the level of ICTIND is higher than 0.299 , but lower than 1.463 , ITR will have a positive strong response to ICTIND but this response is not as strong as the response of ITA to ICTIND.

When the level of ICTIND is higher than 1.463, the ITR will not have a significant response to ICTIND. This indicates that the ICT infrastructure is not conducive to ITR in countries with low ICT infrastructure levels. On the contrary, ICT infrastructure in countries with high ICT infrastructure levels will enhance ITR. To sum up, the level ICT infrastructure is an important factor that results in developing the truism sector in the top10 African tourism destinations when ICT infrastructure reaches to a certain level. In the sense that, when the ICT infrastructure is at lower level (lower threshold), the top10 African tourism destinations can hardly improve their tourism sector development. Whereas, when the level of ICT infrastructure is between the threshold values, the top 10 African tourism destinations can effectively and substantially enhance their presence and become more competitive in international tourism market leading to increase the demand for tourism services and eventually enhance tourism sector development. In other words, the top 10 African tourism destinations can maximize the benefits of information technology only when its level between the two thresholds.

The results of this study shed the light on important policy implications. Because ICT infrastructure has shown a positive and strong relationship with tourism development only when the level of ICT infrastructure reaches a certain threshold given that many African destinations have begun to enhance the level of investment in ICT infrastructure sectors. Therefore, African policymakers in tourism industry need to consider ICT infrastructure trends to ensure that the potential benefits from ICT infrastructure are fully maximized to improve tourism sector. Based on the above research conclusions, the threshold of ICT infrastructure to fully maximize the befits from ICT infrastructure in developing tourism sector is relatively low in the majority of top 10 African countries expect for Egypt, Morocco and Tunisia. The lack of ICT infrastructure contribution in developing tourism sector in most of the African destinations can be attributed to lower penetration of the technology and lack of ICT skill. Therefore, countries with lower ICT infrastructure should encourage R\&D investment in ICT sectors, speed up communication constructions, provide high-speed internet 
facilities, reduce the cost of internet to be affordable by individuals and tourism enterprises, and pay attention to ICT infrastructure development. The findings also, have implications for academics researches by opening up new views on the relationship between ICT infrastructure and tourism sector development in emerging markets. Therefore, future researches are encouraged to further investigate in the effect of ICT infrastructure on tourism development in emerging and advanced markets under different threshold of financial development, country stability, and institutional quality.

\section{REFERENCES}

Adeola, O., \& Evans, O. (2020). ICT, infrastructure, and tourism development in Africa. Tourism Economics, 26(1), 97-114. https://doi.org/10.1177/1354816619827712

Adeola, O., \& Evans, O. (2019). Digital tourism: mobile phones, internet and tourism in Africa. Tourism Recreation Research, 44(2), 190-202. https://doi.org/10.1080/02508281.2018.1562662

Ankomah, P., \& Larson, T. (2019). Virtual tourism and its potential for tourism development in sub-Saharan Africa. In Advanced methodologies and technologies in digital marketing and entrepreneurship (pp. 584-595). IGI Global. https://doi.org/10.4018/978-1-5225-7766-9.ch045

Bahrini, R., \& Qaffas, A.A. (2019). Impact of information and communication technology on economic growth: Evidence from developing countries. Economies, 7(1), 21. https://doi.org/10.3390/economies7010021

Beda, K.F.G. (2019). Information and Communication Technologies in Africa: Levels, Trends and Perspectives. In Smart Economy in Smart African Cities, 447-479, Springer. https://www.springer.com/gp/book/9789811334702

Bethapudi, A. (2013). The role of ICT in tourism industry. Journal of applied economics and business, 1(4), 67-79. http://www. aebjournal.org/articles/0104/010406.pdf

Butler, G., \& Rogerson, C.M. (2016). Inclusive local tourism development in South Africa: Evidence from Dullstroom. Local Economy, 31(1-2), 264-281. https://doi.org/10.1177/0269094215623732

Buhalis, D. (2003). E-Tourism: information technology for strategic tourism management. Essex: Pearson Education Limited. file:///C:/Users/user/Downloads/Buhalis_Dimitrios_E_tourism_information.pdf

Buhalis, D. (1998). Strategic use of information technologies in the tourism industry. Tourism management, 19(5), 409-421. https://doi.org/10.1016/S0261-5177(98)00038-7

Chen, Y., Gong, X., Chu, C.C., \& Cao, Y. (2018). Access to the internet and access to finance: Theoryandevidence. Sustainability,10(7), 25-34. https://doi.org/10.3390/su10072534

Dritsakis, N. (2004). Co-integration analysis of German and British tourism demand for Greece. Tourism management, 25(1), 111-119. https://doi.org/10.1016/S0261-5177(03)00061-X

Firoiu, D., \& Croitoru, A.G. (2013). Tourism and tourism infrastructure from the perspective of technological changes. Romanian Economic and Business Review, 8(2), 93-103.https://EconPapers.repec.org/RePEc:rau:journl:v:8:y:2013:i:2:p:93-103

Gössling, S. (2021). Tourism, technology and ICT: a critical review of affordances and concessions. Journal of Sustainable Tourism, 29(5), 733-750. https://doi.org/10.1080/09669582.2021.1873353

Gretzel, U., Sigala, M., Xiang, Z., \& Koo, C. (2015). Smart tourism: foundations and developments. Electronic Markets, 25(3), $179-188$. https://doi.org/10.1007/s12525-015-0196-8

Hansen, B.E. (1999). Threshold effects in non-dynamic panels: Estimation, testing, and inference. Journal of econometrics, 93(2), 345368. https://doi.org/10.1016/S0304-4076(99)00025-1

Katircioglu, S., Katircioğlu, S., \& Altinay, M. (2018). Interactions between tourism and financial sector development: evidence from Turkey. The Service Industries Journal, 38(9-10), 519-542. https://doi.org/10.1080/02642069.2017.1406479

Khoshnevis, Yazdi, S., \& Khanalizadeh, B. (2017). Tourism demand: A panel data approach. Current Issues in Tourism, 20(8), 787-800. https://doi.org/10.1080/13683500.2016.1170772

Koçak, E., Ulucak, R., \& Ulucak, Z.Ş. (2020). The impact of tourism developments on CO2 emissions: An advanced panel data estimation. Tourism Management Perspectives, 33, 100611. https://doi.org/10.1016/j.tmp.2019.100611

Kumar, N., \& Kumar, R.R. (2020). Relationship between ICT and international tourism demand: A study of major tourist destinations. Tourism Economics, 26(6), 908-925. https://doi.org/10.1177/1354816619858004

Law, R., Chan, I.C.C., \& Wang, L. (2018). A comprehensive review of mobile technology use in hospitality and tourism. Journal of Hospitality Marketing \& Management, 27(6), 626-648. https://doi.org/10.1080/19368623.2018.1423251

Law, R., \& Jogaratnam, G. (2005). A study of hotel information technology applications. International Contemporary Hospitality Management, 17(2), 170-180. https://doi.org/10.1108/09596110510582369

Lee, J.W., \& Brahmasrene, T. (2013). Investigating the influence of tourism on economic growth and carbon emissions: Evidence from panel analysis of the European Union. Tourism management, 38, 69-76. https://doi.org/10.1016/j.tourman.2013.02.016

Lim, C. (2004). The major determinants of Korean outbound travel to Australia. Mathematics and Computers in Simulation, 64(3-4), 477-485. https://doi.org/10.1016/S0378-4754(03)00113-7

Liu, N., \& Fan, F. (2020). Threshold effect of international technology spillovers on China's regional economic growth. Technology Analysis \& Strategic Management, 32(8), 923-935. https://doi.org/10.1080/09537325.2020.1729977

Ma, J.X., Buhalis, D., \& Song, H. (2003). ICTs and Internet adoption in China's tourism industry. International Journal of Information Management, 23(6), 451-467. https://doi.org/10.1016/j.ijinfomgt.2003.09.002

Madhukar, V., \& Sharma, D. (2019). The role of information technology applications in profitability. Worldwide Hospitality and Tourism Themes, 11 (4), 429-437. https://doi.org/10.1108/WHATT-04-2019-0025

Martins, L.F., Gan, Y., \& Ferreira-Lopes, A. (2017). An empirical analysis of the influence of macroeconomic determinants on World tourism demand. Tourism Management, 61, 248-260. https://doi.org/10.1016/j.tourman.2017.01.008

Musakwa, M.T., \& Odhiambo, N.M. (2021). Tourism and financial development nexus in Kenya: A multivariate approach. Journal of Transnational Management, 26(1), 58-74. https://doi.org/10.1080/19407963.2020.1856860

Naradda, Gamage, S.K., Hewa Kuruppuge, R., \& Haq, I.U. (2017). Energy consumption, tourism development, and environmental degradation in Sri Lanka. Energy Sources, Part B: Economics, Planning, and Policy, 12(10), 910-916. https://doi.org/10.1080/15567249.2017.1324533

Nemec Rudez, H. (2008). The GDP impact on international tourism demand: A Slovenia based case. Tourism and hospitality management, 14(2), 217-228. https://hrcak.srce.hr/181026

Ohlan, R. (2017). The relationship between tourism, financial development and economic growth in India. Future Business Journal, 3(1), 9-22. https://doi.org/10.1016/j.fbj.2017.01.003 
Okupe, A., Ward, T., \& Adeola, O. (2018). Enhancing hospitality and tourism industry competitiveness in Sub-Saharan Africa. In Africa's competitiveness in the global economy, 137-167). https://doi.org/10.1007/978-3-319-67014-0_6

Ponelis, S.R., \& Holmner, M.A. (2015). ICT in Africa: Building a Better Life for All. Information Technology for Development, 21(2), 163-177.https://doi.org/10.1080/02681102.2015.1010307

Quadri, D.L., \& Zheng, T. (2010). A revisit to the impact of exchange rates on tourism demand: The case of Italy. The Journal of Hospitality Financial Management, 18(2), 47-60. https://doi.org/10.1080/10913211.2010.10653894

Rasool, H., Maqbool, S., \& Tarique, M. (2021). The relationship between tourism and economic growth among BRICS countries: a panel cointegration analysis. Future Business Journal, 7(1), 1-11.https://fbj.springeropen.com/articles/10.1186/s43093-020-00048-3

Saayman, A., \& Saayman, M. (2015). An ARDL bounds test approach to modelling tourist expenditure in South Africa. Tourism Economics, 21(1), 49-66. https://doi.org/10.5367/te.2014.0436

Salman, A.K. (2003). Estimating tourist demand through co-integration analysis: Swedish data. Current Issues in Tourism, 6(4),323-339. https://doi.org/10.1080/13683500308667959

Shahbaz, M., Kumar, R.R., Ivanov, S., \& Loganathan, N. (2017). The nexus between tourism demand and output per capita with the relative importance of trade openness and financial development: A study of Malaysia. Tourism Economics, 23(1), 168-186. https://doi.org/10.5367/te.2015.0505

Sharma, A., Vashishat, T., \& Rishad, A. (2019). The consequences of exchange rate trends on international tourism demand: evidence from India. Journal of Social and Economic Development, 21(2), 270-287. https://doi.org/10.1007/s40847-019-00080-2

Surugiu, C., Leitão, N.C., \& Surugiu, M.R. (2011). A panel data modelling of international tourism demand: Evidences for Romania. Economic research-Ekonomska istraživanja, 24(1), 134-145. https://doi.org/10.1080/1331677X.2011.11517450

Toader, E., Firtescu, B.N., Roman, A., \& Anton, S.G. (2018). Impact of information and communication technology infrastructure on economic growth: An empirical assessment for the EU countries. Sustainability, 10(10), 37-50. https://doi.org/10.3390/su10103750

Tan, G.W.H., Lee, V.H., Lin, B., \& Ooi, K.B. (2017). Mobile applications in tourism: the future of the tourism industry? Industrial Management \& Data Systems. 117(3), 560-581. https://doi.org/10.1108/IMDS-12-2015-0490

Toh, R.S., Khan, H., \& Goh, L. (2006). Japanese demand for tourism in Singapore: A cointegration approach. Tourism Analysis, 10(4), 369-375. https://doi.org/10.3727/108354206776162831

Tung, L. (2019). Does exchange rate affect the foreign tourist arrivals? Evidence in an emerging tourist market. Management Science Letters, 9(8), 1141-1152. https://doi.org/10.5267/j.msl.2019.5.001

Ukpabi, D.C., \& Karjaluoto, H. (2017). Consumers' acceptance of information and communications technology in tourism: A review. Telematics and Informatics, 34(5), 618-644. https://doi.org/10.1016/j.tele.2016.12.002

Vita, G.D., \& Kyaw, K.S. (2013). Role of the exchange rate in tourism demand. Annals of Tourism Research, 43, 624-627. https://doi.org/10.1016/j.annals.2013.07.011

Yenisehirlioglu, E., \& Bayat, T. (2019). The relationship between tourism income and financial development in the MENA countries. Journal of Business Research, 11(2), 1183-1190. https:// doi.org/10.20491/isarder.2019.664

Wamboy, E.F., Nyaronga, P.J., \& Sergi, B.S. (2020). What are the determinant of international tourism in Tanzania? World Development Perspectives, 100175. https://doi.org/10.1016/j.wdp.2020.100175

Webber, A.G. (2001). Exchange rate volatility and co-integration in tourism demand. Journal of Travel research, 39(4), 398-405. https://doi.org/10.1177/004728750103900406

*** Good Work Labs (2016). Accessed 03.23.2016. http://www.goodworklabs.com/how-mobile-app-benefits-travel-andtourism-industry/

*** International Telecommunication Union's, World indicator (2017). https://www.itu.int/itu-d/sites/statistics/

*** Statistics (2018). https://www.statista.com/statistics/1232306/share-of-tourism-employment

*** Statistics (2019). https://www.statista.com/statistics/1232306/share-of-tourism-employment

*** World Travel and Tourism Council (2018). Retrieved from https://wttc.org/Research /Economic-Impact.

Article history: Received: 07.07.2021 Revised: 12.11.2021 Accepted: 01.12.2021 Available online: 31.12 .2021 